\title{
INVOLVEMENT OF ADOLESCENTS FROM NORTHERN PORTUGAL WITH ALCOHOL
}

\author{
Isabel Amorim Gonçalves ${ }^{1}$, Amâncio António de Sousa Carvalho², Elisabete Pimenta Araújo Paz ${ }^{3}$
}

\footnotetext{
${ }^{1}$ M.Sc. in Community Nursing. Nurse at the Hotel Sénior das Romanas. Pedras Salgadas, Portugal. E-mail: isabel.g@live.com.pt

2 Ph.D. in Child Studies. Professor, Escola Superior de Enfermagem da Universidade de Trás-os-Montes e Alto Douro. Vila Real, Portugal. Departamento de Enfermagem de Saúde Mental e Comunitária, Centro de Investigação em Estudos da Criança, Universidade do Minho. Braga, Portugal. E-mail: amancioc@utad.pt

${ }^{3}$ Ph.D. in Nursing. Professor, Departamento de Enfermagem de Saúde Pública, Escola de Enfermagem Anna Nery, Universidade Federal do Rio de Janeiro. Rio de Janeiro, Rio de Janeiro, Brazil. E-mail: bete.paz@gmail.com
}

\begin{abstract}
Objective: to analyze the relationship between sociodemographic variables and involvement of adolescents with alcohol.

Method: a cross-sectional descriptive and correlational study, with a quantitative approach, was conducted with a sample of 378 students who attended regular high school in the city of Chaves, in Northern Portugal. A questionnaire that included the Adolescent Alcohol Involvement Scale was used as data collection instrument.

Results: most students were female (60.8\%), aged between 17 and 18 years (53.2\%), and fit in the category "Regular drinker without problems" (79.9\%). Male adolescents were more commonly involved with alcohol $(\mathrm{p}=0.010)$.

Conclusion: involvement with alcohol seems to be in an intermediate level, associated with gender, age group, level of schooling, and religious practice. These results justify the development of community interventions, with the aim of preventing alcohol consumption.

DESCRIPTORS: Alcohol drinking. Adolescent. Peer group. Alcoholic intoxication. Alcohol-related disorders.
\end{abstract}

\section{ENVOLVIMENTO DE ADOLESCENTES DO NORTE DE PORTUGAL COM O ÁLCOOL}

\section{RESUMO}

Objetivo: analisar a relação entre variáveis sociodemográficas e envolvimento de adolescentes com o álcool.

Método: estudo descritivo-correlacional, transversal de abordagem quantitativa, com uma amostra de 378 alunos, que frequentavam o ensino secundário regular, no Concelho de Chaves, Norte de Portugal. Como instrumento de coleta de dados, utilizou-se um questionário que incluía a escala de Envolvimento com o Álcool para Adolescentes.

Resultados: a maioria dos alunos era do sexo feminino (60,8\%), pertencia ao grupo etário dos 17-18 anos (53,2\%) e enquadrava-se na categoria "bebedor habitual sem problemas" (79,9\%). Os adolescentes do sexo masculino tinham um maior envolvimento com as bebidas alcoólicas $(p=0,010)$.

Conclusão: o envolvimento com o álcool parece estar num nível intermediário, relacionado com o sexo, grupo etário, ano de escolaridade e prática de uma religião. Esses resultados justificam o desenvolvimento de intervenções comunitárias, com o objetivo de prevenir o consumo de bebidas alcoólicas.

DESCRITORES: Consumo de bebidas alcoólicas. Adolescente. Grupo associado. Intoxicação alcoólica. Transtornos relacionados ao uso de álcool. 


\section{INVOLUCRAMIENTO DE ADOLESCENTES DEL NORTE DE PORTUGAL CON EL ALCOHOL}

\section{RESUMEN}

Objetivo: analizar la relación entre las variables sociodemográficas y el involucramiento de los adolescentes con el alcohol.

Método: se realizó un estudio descriptivo-correlacional y transversal de enfoque cuantitativo, con una muestra de 378 estudiantes que asisten al colegio regular en el condado de Chaves, Norte de Portugal. Como instrumento de recolección de datos se utilizó un cuestionario que incluía la escala del Involucramiento de los Adolescente con el Uso de Alcohol.

Resultados: la mayoría de los estudiantes de la muestra eran mujeres $(60,8 \%)$, pertenecían al grupo de edad de $17-18$ años (53,2\%) y entraron en la categoría de "bebedor habitual sin problemas" (79,9\%). Los hombres mostraron un mayor involucramiento con las bebidas alcohólicas (Mann-Whitney: $\mathrm{p}=0,010$ ).

Conclusiones: el involucramiento con el alcohol parece estar en un nivel intermedio, siendo relacionado con el sexo, edad, grado y práctica de una religión. Estos resultados justifican realizar intervenciones en la comunidad, para prevenir el consumo.

DESCRIPTORES: Consumo de bebidas alcohólicas. Adolescente. Grupo paritario; Intoxicación alcohólica. Trastornos relacionados con alcohol.

\section{INTRODUCTION}

Adolescence is a life phase where several changes occur. According to the World Health Organization, adolescence takes place from ages 10 to 19 , and is triggered by physical and physiological changes resulted from physiological maturation, as well as sociological changes regarding the transition from childhood to adulthood. ${ }^{1-2}$

The search for new experiences, the self-centeredness of adolescence itself, and a sense of greater invulnerability often lead both adolescents and adults to the adoption of risk behaviors enhanced by alcohol consumption, since this drug consumption is generalized among western world societies. ${ }^{3}$ The proportion of adolescents with harmful and dangerous consumption patterns increased in the first decade of the second millennium, and for most individuals, the first consumption experiences tend to occur at the beginning of adolescence. ${ }^{4}$

In a study on alcohol, tobacco, and drug consumption conducted in Portugal with a sample of 13,000 students from 7 th grade to 12 th grade, aged between 13 and 18 years, the consumption of alcohol was $74.0 \%$, and the most consumed alcoholic beverages were hard liquors. ${ }^{5}$

This prevalence of alcohol consumption in Portugal is a little lower than the mean of the 36 countries that participated in the study Substance Use Among Students (ESPAD), which was 79.0\%. In this study, alcohol consumption was very different among the participating countries, not showing a clear geographical pattern. The highest proportions were found in Czech Republic, Denmark, Germany, Greece and Monaco (approximately 90\%). The lowest proportions were found in Iceland and Albania (lower than $50 \%$ ). High consumption of alcohol is more frequent among boys, but there are countries where values are higher among girls. The most consumed alcoholic beverages were beer and hard liquors. ${ }^{6}$

Different alcohol consumption rates were found among continents, with higher prevalence in the European continent than in the American continent, as in the case of the USA (50\%), Mexico $(61.8 \%),{ }^{7}$ and Brazil (42.4\%). ${ }^{8}$ Brazil presents an alcohol consumption pattern per capita lower than countries such as Japan (Asian continent), the USA, and Germany. ${ }^{9}$

In Portugal, the National Health Plan 20122016 makes reference to this matter called "A youth searching for a healthy future", which highlights the increase in alcohol consumption in the age group of 15-24 years and indicates the National Plan to Reduce Alcohol-Related Problems as a reference in the fight against this problem, which is considered an area with recommendation for intervention and classified as health determinant for the reduction of alcohol consumption. ${ }^{10}$

Alcohol is the most used psychoactive substance by adolescents and young adults, both in the European and in the American continent. Although its consumption in adolescence is illegal, it is still considered an important public health matter, because it is the greatest risk factor for the health of this group..$^{11-13}$

Studying adolescents' health behaviors and factors that influence them is essential for the development of health education policies, health promotion programs, and interventions directed to this age group. Most of adolescents' behaviors might directly or indirectly influence their short-and long-term health. ${ }^{14}$

The following problem emerges from the context of this theme: which sociodemographic factors are associated with the involvement with alcohol 
of adolescents who attend high school at public schools in the city of Chaves, in Northern Portugal? Studies on involvement of adolescents with alcohol have already been conducted in Portugal and other countries. However, there are not many studies on the population of high school students, and studies with this purpose have not been conducted in this Portuguese region. Therefore, this study is relevant to undertake interventions in this population, making it necessary to understand its behavioral characteristics regarding this consumption.

The objective of the present study was to analyze the relationship between sociodemographic variables and the involvement of adolescents with alcohol.

\section{METHOD}

A cross-sectional descriptive and correlational study ${ }^{15}$ that integrates the study of alcohol consumption patterns of adolescents enrolled in 10th, 11th, and 12th grades at public schools of the city of Chaves, in Northern Portugal, during 2012 and 2013 terms.

The population of this study was made up of high school students of 10th, 11th and 12th grades (regular education), who attended the three existing public schools in the city of Chaves, Portugal, in 2012 and 2013, henceforth designated A, B, and $\mathrm{C}$ for ethical reasons, totaling 979 individuals.

The inclusion criteria were: a) Adolescents who attended high school (regular education) in 2012 and 2013; b) Adolescents from both genders, aged 15 years or older.

The convenience sampling was made up of 119 students from School A, 127 students from School B, and 132 students from School C, totaling 378 students, approximately $38.61 \%$ of the population.

The Adolescent Alcohol Involvement Scale (AAIS) developed by Mayer \& Filstead and validated for the Portuguese population was used as data collection instrument. ${ }^{16}$ This self-assessment instrument, which is specifically directed to young populations, is based on characteristic features of alcohol consumption pattern in this age group. The aim of this instrument is to measure the degree of relationship of adolescents to the consumption of alcohol and determine the severity of problems associated with such consumption. It is a self-administered scale composed of variables of ordinal measurement level.

The data collection instrument was made up of 14 closed-ended questions, with the purpose of evaluating different responses, according to the frequency and intensity of alcohol consumption. The total score ranged from 0 to 79 points. The results are grouped in five categories: Abstainer (0 points); Social drinker (1-19 points); Regular drinker without problems (20-41 points); Regular drinker with problems (42-57 points); and Alcoholic like (58-79 points). That is, the highest score corresponds to a greater involvement of adolescents with alcohol.

The present study was approved by the General Board of the Ministry of Education and Science, Department for Monitoring of Studies in Educational Institutions, with reference to the authorization order of the survey no. 0351800001, registered on 11/26/2012. After approval, formal authorization from directors of the education council of each school that participated in this study was requested for application of the questionnaire. They all confirmed their favorable opinion.

Data collection occurred from April to May 2013, in the three public schools of the city of Chaves, Portugal. After obtaining authorization for the application of questionnaires, a meeting with class directors and professors was held to present the objectives of the study, provide information about the study's questions, standardize the data collection procedure, and emphasize the importance of anonymity. After that, a signed informed consent form was obtained from parents/guardians of underage students and adolescents who agreed to participate in the study. After receiving the informed consent forms, the professors distributed the self-administered questionnaires to their groups and, after filling in the questionnaires, the students placed them in a box for this specific purpose. At the end of a period defined with the professors, the researchers visited the participant schools to collect the questionnaires. In some schools, a second visit was required to retrieve as many questionnaires as possible.

Descriptive analyses (calculation of absolute and relative frequencies) of variables were carried out; and categories of use and frequency of alcohol consumption, named AAIS Categories (Abstainer, Social drinker, Regular drinker without problems; Regular drinker with problems, and Alcoholic like) were associated with sociodemographic characteristics of the students. The associations were analyzed by means of the Mann-Whitney (MW) and KruskalWallis (KW) tests, which are recommended for the study of inferences based on ordinal variables. ${ }^{17}$ Analyses were carried out through the Statistical Package for the Social Sciences 19.1 (IBM SPSS®). 
Sociodemographic characterization of the sample of students who participated in the study was carried out by gender, age group, school, level of schooling, and religious practice.

\section{RESULTS}

Most participants (60.8\%) were female, aged between 17 and 18 years (53.2\%), the largest group of students attended School A (34.9\%), were in 12th grade $(45.2 \%)$, and practiced some religion (61.4\%). The mean age was 16.7 years $(\mathrm{SD}= \pm 1.3$ years) ranging from 15 to 21 years (Table 1 ).

Table 1 - Sociodemographic characteristics of the sample of students. City of Chaves, Portugal, 2013. $(\mathrm{n}=378)$

\begin{tabular}{llcc}
\hline \multicolumn{1}{c}{ Variables } & & $\mathbf{n}$ & $\mathbf{\%}$ \\
\hline Gender & Male & 148 & 39.2 \\
Age group & Female & 230 & 60.8 \\
& 15-16 years & 140 & 37.0 \\
& 17-18 years & 201 & 53.2 \\
School attended by students & $\geq 19$ years & 37 & 9.8 \\
& $\mathrm{~A}$ & 132 & 34.9 \\
& $\mathrm{~B}$ & 119 & 31.5 \\
Level of schooling & $\mathrm{C}$ & 127 & 33.6 \\
& 10th grade & 116 & 30.7 \\
Religious practice & 11th grade & 91 & 24.1 \\
& 12th grade & 171 & 45.2 \\
& No & 146 & 38.6 \\
& Yes & 232 & 61.4 \\
\hline
\end{tabular}

No significant differences were found among students of the schools regarding gender, $\left(c^{2}: p \geq\right.$ 0.072). There was a higher proportion of girls in two of the schools, but they differed regarding age group $\left(c^{2}: p<0.001\right)$, that is, School A had the highest proportion of students from the age group of 15-16 years and School $\mathrm{C}$ had the highest proportion of students from the age group of 17-18 years.

Of the total sample, $86.8 \%$ of the students considered themselves alcohol consumers. The total AAIS score presented a mean of $24.93 \pm 9.631$, with minimum of 0 and a maximum of 62 points. The mean of the male gender was 26.9 points, and was higher than that for females. The age group of $\geq 19$ years obtained the highest mean, 27.27 points.

The largest proportion of students of the sample fit in the category Regular drinker without problems (79.9\%). However, a residual percentage was found in the category Regular drinkers with problems (1.1\%) and in the category Alcoholic like $(0.3 \%)$. Only one female student fit in this last category.

Regarding the distribution of students by gender, the proportion of female adolescents who fit in the categories of lesser involvement was higher than that of male adolescents, being more than the double in the category Social drinker. The situation reversed in the two following categories of greater involvement, in which proportions of male adolescents were higher. There were not female adolescents in the category Regular drinker with problems.

Regarding age groups, the proportion of students of the age group of 15-16 years was higher in the two categories of lesser involvement with alcohol than in age groups of higher age. This position reversed in the following categories, which showed a progressive increase in proportions as age increases, except for the last category Alcoholic like, in which the only case belongs to the age group of 17-18 years (Table 2 ).

Table 2 - AAIS categories, by gender and age group. City of Chaves, Portugal, 2013. (n=378)

\begin{tabular}{|c|c|c|c|c|c|c|}
\hline \multirow[t]{2}{*}{ AAIS categories } & \multicolumn{2}{|c|}{ Gender (\%) } & \multicolumn{3}{|c|}{ Age group (\%) } & \multirow{2}{*}{$\begin{array}{l}\text { Total }(\%) \text { of } \\
\text { the sample }\end{array}$} \\
\hline & Male & Female & $15-16$ & 17-18 & $>19$ & \\
\hline Abstainer & 6.8 & 7.8 & 14.9 & 3.5 & 0.0 & 7.4 \\
\hline Social drinker & 6.1 & 14.8 & 12.8 & 10.5 & 10.8 & 11.4 \\
\hline Regular drinker without problems & 84.5 & 77.0 & 71.6 & 84.5 & 86.5 & 79.9 \\
\hline Regular drinker with problems & 2.7 & 0.0 & 0.7 & 1.0 & 2.7 & 1.1 \\
\hline Alcoholic like & 0.0 & 0.4 & 0.0 & 0.5 & 0.0 & 0.3 \\
\hline
\end{tabular}

Involvement with alcohol differed significantly regarding gender $(\mathrm{MW}: \mathrm{p}=0.010)$, that is, the male gender obtained a mean position higher than the feminine gender, which means a greater involvement with alcohol in male adolescents.
Regarding the age group, involvement with alcohol also differed significantly, $(\mathrm{KW}: \mathrm{p}=0.001)$, that is, students who belonged to the age group of $\geq 19$ years obtained the highest mean position, which means a greater involvement with alcohol. 
The same was found as for level of schooling (KW: $\mathrm{p}=0.000$ ), in which students who attended 12th grade obtained the highest mean position, which means a greater involvement with alcohol.

Considering schools, no significant differences were found among students who attended them with regard to the involvement with alcohol (KW: $\mathrm{p}=0.120)$.

Finally, the involvement of students with alcohol differed significantly regarding the practice of a religion $(\mathrm{MW}: \mathrm{p}=0.002)$, that is, those who did not practice any religion obtained a higher mean position, which means they have greater involvement with alcohol (Table 3).

Table 3 - Results of the statistical tests between the variables AAIS categories* and attributes. City of Chaves, Portugal, 2013. $(n=378)$

\begin{tabular}{llcccc}
\hline Variables & & $\mathbf{n}$ & Mean position & Test value & p-value \\
\hline Gender & Male & 148 & 202.09 & MW & 0.010 \\
& Female & 230 & 181.40 & 15156.500 & \\
Age group & 15-16 years & 141 & 170.59 & KW & 0.001 \\
& 17-18 years & 200 & 199.42 & 14.200 & \\
Level of schooling & $\geq 19$ years & 37 & 207.99 & & \\
& 10th grade & 116 & 166.57 & KW & 0.000 \\
School attended by students & 11th grade & 91 & 194.13 & 15.830 & \\
& 12th grade & 171 & 202.59 & & \\
Religious practice & A & 132 & 183.92 & KW & 0.120 \\
& B & 119 & 183.58 & 4.232 & \\
& C & 127 & 200.85 & & \\
& No & 146 & 202.27 & MW & 0.002 \\
\hline
\end{tabular}

*AAIS: Adolescent Alcohol Involvement Scale; MW: Mann-Whitney test; KW: Kruskal-Wallis test.

\section{DISCUSSION}

A study conducted in Portugal with 360 high school adolescents ${ }^{18}$ aged between 14 and 21 years in a school in the city of Vila Nova Famalicão (coastline) and in a school in the city of Bragança (countryside), showed that most students were also female $(59.7 \%)$, which is a proportion slightly lower than that found in the present study. The same was found in the study PINGA (Study on prevalence of alcohol consumption in adolescents) ${ }^{19}$ conducted in the city of Bragança (Northeast of Portugal) with a sample of 1,061 adolescents attending school, aged between 13 and 19 years, in which the proportion of female adolescents was $51.6 \%$, yet lower than that found in the present study.

The results concerning the mean ages agree with those found in a study conducted in the city of Viseu, ${ }^{20}$ whose sample was made up of 917 high school students (10th, 11th, and 12th grades), with a mean age of $16.80 \pm 1.38$ years, minimum age of 14 years and maximum age of 21 years. These results are very similar to those found in the present study, in which the mean age was $16.96 \pm 1.269$ years, minimum age of 15 years and maximum age of 21 years.

Regarding the level of schooling of the students, in the sample of the present study, most students attended 12 th grade $(45.2 \%)$, which differs from the study conducted in the city of Viseu, ${ }^{20}$ in which the largest group of students (46.9\%) attended 11th grade.

The prevalence of alcohol consumers in the sample of the present study was $86.8 \%$, which is a significant percentage, being higher than the prevalence of alcohol consumption found in the study conducted in the cities of Vila Nova de Famalicão and Bragança ${ }^{18}(77.7 \%$ and $66 \%$, respectively). However, this proportion is still slightly lower than that found in the study in the city of Viseu ${ }^{20}(90.6 \%)$. Nonetheless, the study PINGA ${ }^{19}$ showed a prevalence throughout life of $89.8 \%$, which is slightly higher than that found in the present study.

The results of the present study regarding the prevalence of alcohol consumption $(86.8 \%)$ presented a greater involvement of students of the male gender and age group of $\geq 19$ years. Such results are corroborated by a study on psychoactive substance consumption conducted with 678 adolescents of 7 th to 10th grades from a high school with third cycle in the city of Vila Real, ${ }^{21}$ which showed that $49.0 \%$ of the sample reported consuming alcoholic beverages, being $21.5 \%$ female and $27.5 \%$ male, and the oldest of them belonged to the age group of 13-15 
years. The lowest prevalence is justified by the fact that it was a younger sample, still maintaining a difference among genders.

Regarding the AAIS score, the present study obtained a mean of $24.93 \pm 9.631$ points, a minimum of 0 and maximum of 62 points, whereas in the study conducted in the city of Viseu, ${ }^{20}$ the same mean was of $24.62 \pm 9.86$ points, with a minimum of 0 and a maximum of 47 points. In other words, there was a slightly lower mean than that found in the present study, as well as the maximum score, which indicates a greater involvement of the participants in the present study with alcohol.

The results found in a study conducted in the city of Vila Real ${ }^{22}$ with a sample of 501 high school students were higher than those found in the two studies abovementioned, since it obtained a mean of $33.7 \pm 7.7$ points, a minimum of 16 and a maximum of 64 points, which is a score that indicates a greater involvement with alcohol in the group studied.

With regard to the categories of the same scale, most of the sample in the present study fit in the category Regular drinker without problems (79.9\%), and only $0.3 \%$ in the category Alcoholic like, agreeing with the categories of the study conducted in the city of Viseu, ${ }^{20}$ although this study showed a slightly lower percentage than that found in the first category of the present study $(75.3 \%$ and $0.7 \%$, respectively).

The present study showed a relationship between the involvement of the participants with alcohol and age group, level of schooling, and religious practice of students, whereas the study conducted in the city of Vila Real ${ }^{22}$ only showed a relationship to the variable level of schooling. However, whereas the involvement with alcohol consumption in the present study increased from 10th to 12th grade, reflecting the influence from the advance in age, in the study in comparison, the greatest involvement is from 11th grade students, followed by 12th grade and, at last, by 10th grade students. This might be explained by the fact that they are from different school communities.

The study PINGA showed that male adolescents presented a higher alcohol consumption, with significant statistical differences $(p=0.032)$, as shown in the present study on involvement with alcohol. ${ }^{19}$

The results of the present study corroborate the findings of studies conducted in Portugal from 2003 to 2011 with samples of adolescents aged between 13 and 18 years, which showed that alcohol consumption tends to increase linearly with age, being higher among the male gender. ${ }^{23}$

These results corroborate those found in international studies conducted in Argentina. The first was carried out with a sample of 6,736 adolescents aged between 16 and 24 years and the second with 1,328 students aged between 13 to the 15 years. These studies showed a relationship between alcohol consumption and male gender, and increase in age. ${ }^{24-25}$ However, there are studies that show a higher prevalence of consumption among female adolescents, as shown in studies conducted in Brasil. ${ }^{26-28}$ Differences between Brazilian studies and the present study might be explained by the diversity in location, since Portugal, where the present study was conducted, is very traditional, with risk behaviors more associated with the male gender.

The present study contributed to identify the proportion of adolescents involved in alcohol consumption, showing a high proportion of regular drinkers, of whom about $1.4 \%$ were regular drinkers with problems, which indicates the need for urgently helping to rehabilitate adolescents involved with alcohol consumption.

The main limitations of this study are especially associated with the fact that this is a crosssectional study that does not allow for establishing cause-effect relationships, with a non-random sample, not allowing generalization of the results.

Conducting studies of qualitative approach that would allow the identification of reasons that lead male adolescents to a greater involvement with alcohol and the protective effect of religion may be useful to broaden the knowledge obtained in this study.

\section{CONCLUSION}

When considering the AAIS score, the present study shows an intermediate mean between the two main studies in comparison, which means an average involvement with alcohol among students of the sample, strengthened by the fact that most students (79.9\%) fit in the category Regular drinker without problems.

A statistical relationship was found between categories of involvement with alcohol and gender, age group, level of schooling, and religious practice, which were variables that influenced that behavior.

These results justify the development of interventions in community nursing context, with the aim of preventing alcohol consumption in this age group. The present study might be the first stage of a health planning methodology for actions related 
to alcohol consumption, developed by care units of the community, which perform in geographic areas where schools involved in this study are located.

Actions directed to the prevention of alcohol consumption among adolescents must have a multisectoral and continuous nature for awareness of the whole society, involving different partners, such as school community, family, school health teams, and local authorities, and not only interventions with a focus on students.

\section{REFERENCES}

1. United Nations Children`s Fund. (UNICEF). Situação mundial da infância. Adolescência, uma fase de oportunidades [documento na Internet]. Geneve (CH): ONU; 2011 [cited 2014 Mai 24]. Available from: https://www.unicef.pt/18/Relatorio_SOWC_2011. pdf

2. Cobb NJ. Adolescence: continuity, change, and diversity. $7^{\mathrm{a}}$ ed. Sunderland (US): Sinauer Associates; 2010.

3. Goodwin D. Alcoholism: the facts. New York (US): Oxford University Press; 2000.

4. Barroso TMM, Mendes AMO, Barbosa AJF. Programa de prevenção do uso/abuso de álcool para adolescentes em contexto escolar: parar para pensar. Esc Anna Nery. 2013; 17(3):466-73.

5. Feijão F, Lavado E, Calado V. Estudo sobre o consumo de álcool, tabaco e drogas. Grupos etários dos 13 aos 18 anos. Portugal Continental/2011. ECTAD-ESPAD/ Portugal-2011. Lisboa (PT): IDT/NEI; 2011.

6. Hibell B, Guttormsson U, Ahlstrom S, Balakireva O, Bjarnason T, Kokkevi A, et al.; The Swedish Council for Information on Alcohol and other Drugs (CAN). The 2011 ESPAD Report. Substance use among students in 36 European Countries [Internet]. Stockholm (Sweden): CAN; 2012 [cited 2016 Apr 25]. Available from: http://www.espad.org/uploads/ espad_reports / 2011/the_2011_espad_report_ full_2012_10_29.pdf

7. López-Cisneros MA, Villar Luis MA, Alonso Castillo MM, Alonso Castillo MTJ, Rodriguez Aguilar L. Actitud ante el consumo y no consumo de alcohol en estudiantes de Preparatoria - México. Rev Esc Enferm USP [Internet]. 2013 [cited 2016 May 08]; 47(4): 815-21. Available from: http:/ / www.scielo.br/pdf/reeusp/ v47n4/0080-6234-reeusp-47-4-0815.pdf

8. Cardoso LRD, Malbergier A. Problemas escolares e o consumo de álcool e outras drogas entre adolescentes. Psicol Esc e Educ [Internet]. 2014 [cited 2016 May 08]; 18(1): 27-34. Available from: http://www.scielo.br/scielo.php?script=sci_ arttext\&pid=S1413-85572014000100003

9. Acselrad G, Karam ML, David HMS, Alarcon S, Pfeil FM, Andrade CSG. Consumo de bebidas alcoólicas no Brasil. Estudo com base em fontes secundárias [Relatório de Pesquisa na Internet]. Rio de Janeiro: Faculdade latino-americana de Ciências Sociais; 2012 [cited 2016 May 07]. Available from: http:/ / flacso.org.br/files/2015/02/ RelatorioConsumodoAlcoolnoBrasilFlacso05082012. pdf

10. Direção-Geral da Saúde (DGS-P). Plano Nacional de Saúde 2012-2016 [documento na internet]. Lisboa (PT): DGS; 2012 [cited 2014 May 24]. Available from: http:/ / pns.dgs.pt/pns-em-portugues/

11. World Health Organization (WHO). Framework for alcohol policy in the WHO European Region [Internet]. Copenhague: WHO Regional Office for Europe; 2006 [cited 2014 May 24]. Available from: http://www. euro.who.int/_data/assets/pdf_file/0007/79396/ E88335.pdf

12. Veloza Gómez M, Simich L, Strike C, Brands B, Giesbrecht N, Khenti A. Medio social y uso simultáneo de alcohol y tabaco en estudiantes universitarios de Pregrado de Carreras de Ciencias de la Salud de una Universidad, Cundinamarca - Colombia. Texto Contexto Enferm [Internet]. 2012 [cited 2016 Apr 25]; 21(Esp):41-8. Available from: http:/ / www.scielo.br/ pdf/tce/v21nspe/v21nspea05.pdf

13. Caravaca Morera JA, Noh S, Hamilton H, Brands B, Gastaldo D, Wright MGM. Factores socioculturales y consumo de drogas entre estudiantes universitários Costarricences. Texto Contexto Enferm [Internet]. 2015 [cited 2016 Apr 25]; 24(Esp): 145-53. Available from: http:/ / www.scielo.br/pdf/tce/v24nspe/01040707-tce-24-spe-00145.pdf

14. Matos MG, Simões C, Carvalhosa SF, Reis C. A saúde dos adolescentes portugueses [Internet]. Lisboa (PT): FMH/PEPT- Saúde; 2006 [cited 2014 May 24]. Available from: www.aventurasocial.com

15. Fortin MF, Côté J, Fillion F. Fundamentos e etapas do processo de investigação. Loures (PT): Lusodidacta; 2009.

16. Fonte A, Alves A. O uso da escala de envolvimento com o álcool para adolescentes (AAIS): avaliação das caraterísticas psicométricas. Rev Soc Port Alcoologia. 1999; 3(4):17-24.

17. Marôco J. Análise estatística com o PASW Statistics. Lisboa (PT): Report Number; 2010.

18. Magalhães IMM. Consumo de tabaco, álcool e drogas ilícitas dos jovens: um estudo comparativo entre o litoral e o interior [dissertação]. Porto (PT): Universidade Fernando Pessoa; 2010.

19. Reis A, Barros J, Fonseca C, Parreira L, Gomes M, Figueiredo I, et al. Prevalência da ingestão de álcool nos adolescentes: Estudo PINGA. Rev Port Clin Geral. 2011; 27: 338-46.

20. Valente GAA. Auto-regulação e consumo de álcool em adolescentes do distrito de Viseu [dissertação na Internet]. Viseu (PT): Escola Superior de Saúde de Viseu. Instituto Politécnico de Viseu; 2012 [cited 2014 
May 24]. Available from: http://repositorio.ipv.pt/ handle/10400.19/1628

21. Carvalho AAS, Lemos E, Raimundo F, Costa M, Cardoso F, Sousa MC, et al. Caracterização do consumo de substâncias psicoactivas numa população escolar. Rev Toxicodependências. 2007; 13(3):31-6.

22. Minhava V. Consumo de álcool por alunos do ensino secundário do concelho de Vila Real no ano letivo 2012/2013 [Dissertação]. Vila Real (PT): Universidade de Trás-os-Montes e Alto Douro; 2014.

23. Loureiro LMJ, Barroso TMM, Mendes AMO, Rodrigues MA, Oliveira RAA, Oliveira NRN. Literacia em saúde mental de adolescentes e jovens portugueses sobre abuso de álcool. Esc Anna Nery. 2013 jul-set; 17(3):474-81.

24. Débora Acosta l, Ruth Fernández A, PillonSC. Factores sociales para el uso de alcohol en adolescentes y jóvenes. Rev Latino-Am Enfermagem [Internet]. 2011 [cited 2016 Apr 25]; 19(Esp): 171-81. Available from: http://www.scielo.br/pdf/rlae/v19nspe/15.pdf

25. Pierobon M, Barak M, Hazrati S, Jacobsen KH. Alcohol consumption and violence among Argentine
Adolescents. J Pediatria (Rio J) [Internet]. 2013 [cited 2016 Apr 25]; 89(1): 100-07. Available from: http:/ / www.scielo.br/scielo.php?pid=S002175572013000100015\&script=sci_arttext\&tlng=en

26. Malta DC, Mascarenhas MD, Porto DL, Barreto SM, Neto OLM. Exposição ao álcool entre escolares e fatores associados. Rev Saúde Pública [Internet]. 2014 [cited 2016 Apr 25]; 48(1): 52-62. Available from: http:// www.scielo.br/scielo.php?script=sci arttext\&pid=S0034-89102014000100052

27. Pratta EMM, Santos MA. Fatores de risco para o uso na vida e no ano de álcool entre adolescentes do ensino médio. Rev Eletr Saúde Mental Álcool Drog Pública [Internet]. 2013 [cited 2016 Apr 25]; 9(1):18-24. Available from: http://www. scielo.br/scielo.php?script=sci_arttext\&pid=S1415790X2011000500014

28. Moreno RS, Ventura RN, Brêtas JRS. O uso de álcool e tabaco por adolescentes do município de Embu, São Paulo, Brasil. Rev Esc Enferm USP [Internet]. 2010 [cited 2016 Abr 25]; 44(4):969-77. Available from: http://www.scielo.br/scielo.php?script=sci arttext\&pid=S0080-62342010000400016 